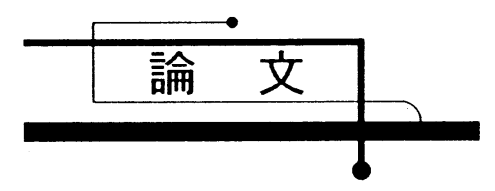

\title{
給水加熱器の伝熱量に及ぼす不凝縮性気体の影響* \\ Effect of Noncondensable Gas on Heat Transfer Rate \\ in a Feed Water Heater
}

\author{
高 森 和 英** \\ TAKAMORI Kazuhide
}

\author{
村 瀬 道 雄** \\ MURASE Michio
}

\begin{abstract}
相 原剛+
AIHARA Tsuyoshi

Abstract In this study, experiments were conducted in order to investigate the effect of noncondensable gas on the condensation heat transfer in a feed-water heater under the conditions of inlet quality $13-100 \%$ and inlet air molar fraction $0-1.2 \%$. The thermal resistance on condensation surface was found to be proportional to the local air molar fraction. A transport equation of noncondensable gas and the experimental equation of thermal resistance on condensation surface were added to the previously developed program with a two-fluid model and condensation heat transfer model. Feed-water heater calculations indicated that the effect of noncondensable gas on the heat transfer was negligibly small under the operation conditions of about $30 \mathrm{ppm}$ in a power plant. Keywords: Noncondensable Gas, Condensation Heat Transfer, Feed Water Heater
\end{abstract}

\section{1. 緒 言}

原子力や火力発電プラントでは、給水加熱器が 設置されており、タービンからの蒸気や高温ドレ ン水との熱交換により給水を加熱する。給水加熱 器内の高温・高圧条件での蒸気凝縮を伴う二相流 挙動は、給水加熱器の伝熱特性に影響する。従 来、伝熱量は実機での実績や実験結果に基づき上 段・下段の伝熱管群の平均値として評価してお り、ボイド率や気液の速度分布が伝熱量に及ほす 影響は明らかにされていなかった。これまでに、 一次元による熱流動解析[1]が報告されている が、凝縮熱伝達の実験式による加熱量評価が目的 であり、二相流挙動については考慮されていな w。
そこで、本研究においては、二流体モデルを用 いた汎用二相流解析プログラム[2]を基にして、 給水加熱器内の蒸気・液滴 - 液膜の挙動と凝縮伝 熱を計算できるように改良した[3]。この凝縮伝 熱モデルを $4 \times 32$ 段の伝熱管群を用いた大気圧 条件での実験により検証[4]するとともに、給水 加熱器の構造が伝熱性能に及ほす影響を評価した [5]。

一方、給水加熱器内の不凝縮性気体の影響につ いては、濃度が低いため従来から無視されてお り、定量的に評価した例はない。そこで、本報告 では、二相流中での不凝縮性気体が凝縮伝熱に及 ほす影響を評価するため、凝縮伝熱実験により不 凝縮性気体による凝縮面熱抵抗を测定した。ま

\footnotetext{
* 1997.3 .26 受付

** 侏立製作所電力・電機開発本部 テ319-12 茨城県日立市大みか町7-2-1 TEL(0294)52-8442 FAX(0294)53-7664

+ (株立製作所日立工場
} 
た、解析プログラムに不凝縮性気体の輸送方程式 を追加するとともに、伝熱モデルに凝縮面熱抵抗 の実験式を追加して、不凝縮性気体が給水加熱器 の伝熱性能に及ぽす影響を評価した。

\section{2. 給水加熱器の概要}

給水加熱器の構造の一例をFig. 1 に、断面を

Fig. 2 に示す。上部から抽気蒸気及び二相流が流 入し、横置きU字形の伝熱管内の給水を加熱す る。凝縮水は下部のドレン管から排水され、より 低温・低圧の給水加熱器に供給される。二相流と 蒸気の入口下方には、伝熱管への衝撃を緩和する バッフル板が設けられている。伝熱管群は複数の 伝熱管支持板で支持されており、伝熱管支持板に より伝熱管外部の流路は複数の領域に区分されて いる。U字形の伝熱管は、低温側の下部と高温側 の上部に分かれ、Fig. 2 に示すように、下部伝熱 管群と上部伝熱管群を形成している。各伝熱管は 千鳥格子状に配置されている。混入する不凝縮性 気体を効果的に排気するために、断面中心にベン 卜管が、その周囲にベント管案内板とサイドバッ フル板が設けられている。

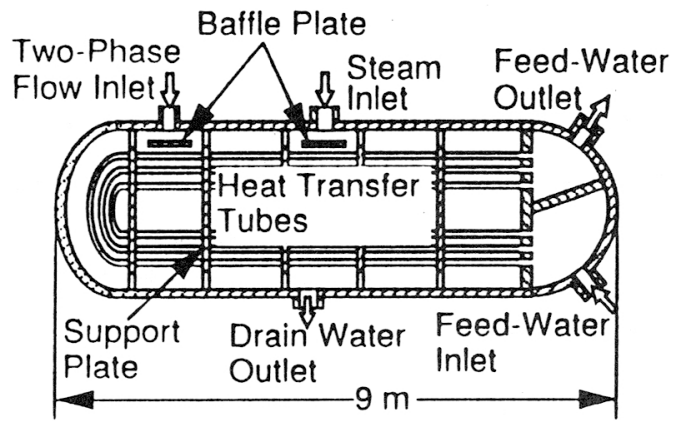

Fig. 1 Structure of feed-water heater

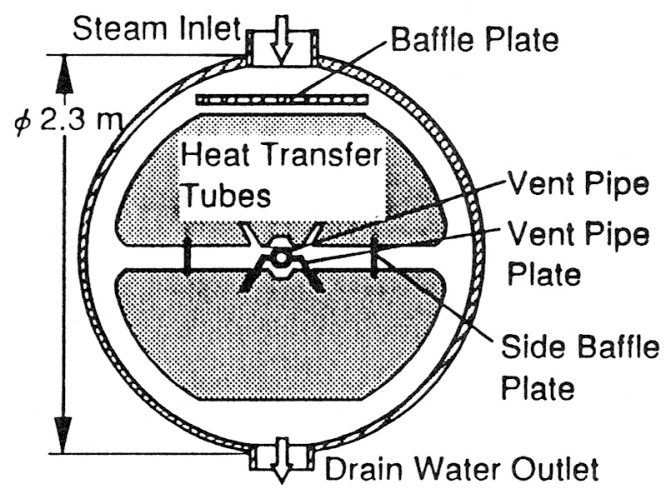

Fig. 2 Cross section of feed-water heater

\section{3. 計算方法}

\section{1 二相流解析}

本研究で使用した二相流解析プログラム[2]で は、二流体モデルとポーラスメディア近似を用い ており、複雑な形状の流路内での気液の速度差を 考慮した計算ができる。基礎方程式は以下の通り である。

[質量保存式]

$\gamma_{\mathrm{v}} \partial / \partial \mathrm{t}\left(\alpha_{\mathrm{k}} \rho_{\mathrm{k}}\right)+\nabla\left(\gamma_{\mathrm{s}} \alpha_{\mathrm{k}} \rho_{\mathrm{k}} \mathrm{U}_{\mathrm{k}}\right)=\gamma_{\mathrm{v}} \Gamma_{\mathrm{k}}$

[運動量保存式]

$\gamma_{\mathrm{v}} \partial / \partial \mathrm{t}\left(\alpha_{\mathrm{k}} \rho_{\mathrm{k}} \mathrm{U}_{\mathrm{k}}\right)+\nabla\left(\gamma_{\mathrm{s}} \alpha_{\mathrm{k}} \rho_{\mathrm{k}} \mathrm{U}_{\mathrm{k}} \cdot \mathrm{U}_{\mathrm{k}}\right)$

$=\gamma_{\mathrm{v}}\left(-\alpha_{\mathrm{k}} \nabla \mathrm{P}_{\mathrm{k}}+\mathrm{K}_{\mathrm{k}}+\alpha_{\mathrm{k}} \rho_{\mathrm{k}} \mathrm{g}+\mathrm{F}_{\mathrm{ik}}+\mathrm{F}_{\mathrm{wk}}\right.$

$\left.+\alpha_{k} \tau_{k}\right)$

[エネルギー保存式]

$\gamma_{\mathrm{v}} \partial / \partial \mathrm{t}\left\{\alpha_{\mathrm{k}} \rho_{\mathrm{k}}\left(\mathrm{e}_{\mathrm{k}}+\mathrm{U}_{\mathrm{k}} 2 / 2\right)\right\}$

$+\nabla\left\{\gamma_{\mathrm{s}} \alpha_{\mathrm{k}} \rho_{\mathrm{k}} \mathrm{U}_{\mathrm{k}}\left(\mathrm{e}_{\mathrm{k}}+\mathrm{U}_{\mathrm{k}} 2 / 2+\mathrm{P}_{\mathrm{k}} / \rho_{\mathrm{k}}\right)\right\}$

$=\gamma_{\mathrm{v}}\left\{\mathrm{E}_{\mathrm{k}}-\mathrm{P}_{\mathrm{k}} \partial / \partial \mathrm{t}\left(\alpha_{\mathrm{k}}\right)+\mathrm{q}_{\mathrm{ik}}+\mathrm{q}_{\mathrm{wk}}\right.$

$\left.\left.+\alpha_{\mathrm{k}} \rho_{\mathrm{k}} \mathrm{U}_{\mathrm{k}} \mathrm{g}\right)\right\}$

数值計算法として、コントロールボリューム法 とSIMPLE法を使用している[2,6]。主要な構成式 である気液相間摩擦にはIshiiの式[7]を使用し た。本研究が対象とする流動様式は噴霧流である ため、蒸気の流動を計算した後に液滴の流動を計 算する分散相陽解法を適用し、計算時間を約 11 4 に短縮した。

本報告では、不凝縮性気体の影響を評価するた め、不㠜縮性気体の輸送方程式を追加した。

$\partial / \partial \mathrm{t}\left(\mathrm{C}_{\mathrm{A}}\right)+\nabla\left(\mathrm{U} \mathrm{C}_{\mathrm{A}}\right)=\mathrm{D} \nabla^{2} \mathrm{C}_{\mathrm{A}}$

ここで、 $\mathrm{C}_{\mathrm{A}} 、 \mathrm{D} 、 \mathrm{t}$ 及びUは、それぞれ、不凝縮 性気体のモル分率、搪散係数、時間、速度であ る。

3.2 伝熱モデル

凝縮伝熱量は、蒸気と給水の温度差、伝熱管面 積、熱通過率を用いて計算できる。Fig. 3 に示す ように、蒸気は伝熱管表面で凝縮し、液膜を形成 して重力落下する。このときの熱通過率 K $\mathrm{K}$ 次式 で表わせる。 
$\mathrm{K}=1 /\left(\mathrm{R}_{1}+\mathrm{R}_{2}+\mathrm{R}_{3}+\mathrm{R}_{4}\right)=1 / \mathrm{R}$

ここで、 $\mathrm{R}_{1} 、 \mathrm{R}_{2} 、 \mathrm{R}_{3} 、 \mathrm{R}_{4}$ は、それぞれ、不凝縮 性気体による凝縮面熱抵抗、液膜熱抵抗、伝熱管 材と管污れの熱抵抗、管内対流伝熱による熱抵抗 である。不凝縮性気体の濃度が極めて低い場合に は、凝縮面熱抵抗 $R_{1}$ は無視できる $\left(R_{1}=0\right)$ 。凝縮面 熱抵抗を無視できない場合については後述する。 液膜熱抵抗 $R_{2}$ は液膜の厚さ $\delta_{2}$ と熱伝導率 $\lambda_{w}$ か ら計算できる。

$\mathrm{R}_{2}=\delta_{2} / \lambda_{\mathrm{w}}$

液膜レイノルズ数 $(\mathrm{Re})_{\mathrm{f}}=\mathrm{u}_{\mathrm{m}} 4 \delta / \nu_{\mathrm{w}}$ は 900 末満で あり、液膜は層流として扱える。この場合には、 液膜厚さは、質量保存式と Nusselt 理論から計算 できる。

$Q_{F}=Q_{F U}+Q_{C}+Q_{D}-Q_{E}=2 \rho_{w} u_{m} \delta L N$

ここで、 $\mathrm{Q}_{\mathrm{F}}$ は液膜流量、 $\mathrm{Q}_{\mathrm{FU}}$ は上方の伝熱管群か ら落下寸る液膜流量、 $\mathrm{Q}_{C}$ は凝縮量、 $\mathrm{Q}_{\mathrm{D}}$ は液滴の 液膜への付着量、 $\mathrm{Q}_{\mathrm{E}}$ は液膜からの液滴の飛散量 である。また、L、Nは伝熱管の長さと本数であ

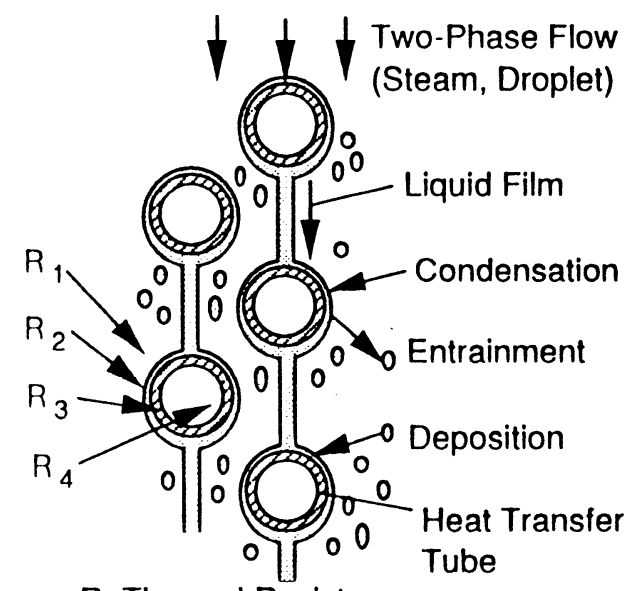

R: Thermal Resistance

Subscripts

1: Noncondensable gas effect

2: Liquid film

3: Tube material with fouling

4: Convection inside tube

Fig. 3 Condensation heat transfer model
る。平均液膜速度 $\mathrm{u}_{\mathrm{m}}$ は Nusselt 理論から求まり、

これと式(7)から平均液膜厚さ $\delta$ は次のようにな る。

$\delta=\left(\mathrm{Q}_{\mathrm{F}} /\left(0.42 \rho_{\mathrm{w}} \mathrm{gLN} / \nu_{\mathrm{w}}\right)\right)^{1 / 3}$

上式は静止蒸気中での理論式に基いており、蒸気 流中での液膜厚さ $\delta_{1}\left(=\lambda_{\mathrm{w}} / \mathrm{h}(\mathrm{Re})\right)$ は気液界面摩 擦により静止蒸気中の液膜厚さ計算值 $\delta_{0}\left(=\lambda_{\mathrm{w}}{ }^{\prime}\right.$ $\mathrm{h}(0))$ より薄くなる。そこで、蒸気流中での液膜 厚さをFujii の式[8]で評価し、式(8)を補正して使 用した。

$$
\delta_{2}=\delta\left(\delta_{1} / \delta_{0}\right)
$$

式(7)において、上方の伝熱管群から落下寸る液 膜流量 $\mathrm{Q}_{\mathrm{FU}}$ 、凝縮量 $\mathrm{Q}_{\mathrm{C}}$ 、液滴の液膜への付着量 $\mathrm{QD}_{D}$ 、液膜からの液滴の飛散量 $\mathrm{Q}_{\mathrm{E}}$ は、それぞれ次 式で表わせる。

$\mathrm{Q}_{\mathrm{FU}}=2 \mathrm{C}_{1} \rho_{\mathrm{w}}\left(\mathrm{u}_{\mathrm{m}} \delta\right)_{\mathrm{U}} \mathrm{LN}$

$\mathrm{Q}_{\mathrm{C}}=\mathrm{E}_{\mathrm{C}^{\prime}} \mathrm{L}^{\prime}$

$\mathrm{Q}_{\mathrm{D}}=\mathrm{K}_{\mathrm{D}} \mathrm{CS}$

$\mathrm{Q}_{\mathrm{E}}=\mathrm{C}_{\mathrm{E}} \mathrm{S}$

ここで、 $\mathrm{C}_{1}$ は上方の伝熱管から下方の伝熱管に 落下寸る液膜流量割合を示し、 $\left(1-\mathrm{C}_{1}\right)$ は液滴と して飛散する割合に対応する。 $\mathrm{E}_{\mathrm{C}}$ は凝縮伝熱 量、 $L^{\prime}$ は凝縮潜熱、 $\mathrm{K}_{\mathrm{D}}$ は液滴伝達係数、 $\mathrm{C}_{\mathrm{E}}$ は液 滴発生率、C は液滴濃度、S は解析メッシュ内の 伝熱管表面皘である。式(7)-(13)を用いて液膜厚 さを計算できる。式(11)の凝縮伝熱量 $\mathrm{E}_{\mathrm{C}}$ は式(5)(9)などによる熱通過率計算值、蒸気と給水の温 度差、伝熱面積から計算する。式(12)、

(13)に拈いて、液滴伝達係数、液滴発生率は、従 来の実験[9]及び実験式[10]からそれぞれ $\mathrm{K}_{\mathrm{D}}=$ $0.10 \mathrm{~m} / \mathrm{s} 、 \mathrm{C}_{\mathrm{E}}=0.11 \mathrm{~kg} / \mathrm{m}^{2} \mathrm{~s}$ を使用した。一方、 式(10)における液膜流量割合 $\mathrm{C}_{1}$ は実機伝熱量解析 から、伝熱量の実績值と一致するように $\mathrm{C}_{1}=0.7$ とした。液滴伝達係数 $\mathrm{K}_{\mathrm{D}}$ を $0.10 \mathrm{~m} / \mathrm{s}$ から $0.05 \mathrm{~m} / \mathrm{s}$ に、液滴発生率 $\mathrm{C}_{\mathrm{E}}$ を $0.11 \mathrm{~kg} / \mathrm{m}^{2} \mathrm{~s}$ から $0.22 \mathrm{~kg} / \mathrm{m}^{2}$ sに変更した場合、液膜厚さの隇少により、伝熱 量がそれぞれ約 $7 \%$ 、約 $2 \%$ 増加した。また、液 膜流量割合 $\mathrm{C}_{1}$ を 0.7 から 0.6 もしくは 0.8 に変更し 
た場合、伝熱量が約 $4 \%$ 増減した。これらを個別 に検証することは困難であるため、 $\mathrm{K}_{\mathrm{D}} 、 \mathrm{C}_{\mathrm{E}}$ を固 定し、 $\mathrm{C}_{1}$ の妥当性を検証した。

\section{3 計算モデルの検証}

上述した伝熱モデル、特に、液膜流量割合 $\mathrm{C}_{1}=$ 0.7の妥当性を検証するため凝縮伝熱実験を実施 した。実験装置は後述するFig.5、実験条件は空 気の混入を除きTable 1と同様である。

不凝縮性気体を混入しない条件 $\left(\mathrm{R}_{1}=0\right)$ で、試 験部入口クオリティをパラメータとして測定した 熱通過率と計算值の比較をFig. 4 [4]に示す。計算 では、液膜流量割合 $\mathrm{C}_{1}=0.7$ 使用しており、測 定值と $\pm 5 \%$ 以内で一致した。 $\mathrm{C}_{1}=0.6$ もくは 0.8 にすると、測定値との相違が増加し、本実験 の範囲内では $\mathrm{C}_{1}=0.7$ が妥当であることを確認し た。

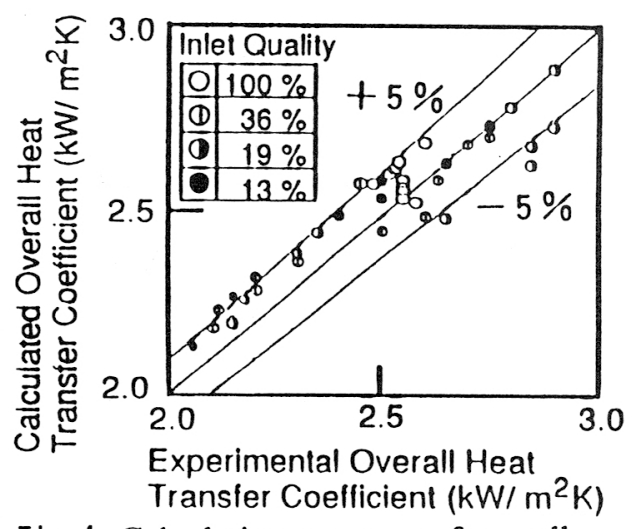

Fig. 4 Calculation accuracy of overall heat transfer coefficient (Falling liquid film ratio $\mathrm{G}=0.7$ )

\section{4.凝縮伝熱実験}

従来から水平円管群外面での凝縮伝熱実験は多 く実施されている[11]。しかし、給水加熱器の特 徵である二相流入の低クオリテイ条件や、不凝縮 気体の混入条件での凝縮伝熱実験は見当たらな い。そこで、入口クオリテイや不凝縮性気体濃度 が凝縮伝熱に及ほす影響を評価するために、凝縮 伝熱実験を実施した。

実験装置の概要をFig. 5 に、実験条件をTable 1 に示す。ボイラからの蒸気と空気ボンベからの空 気を混合するとともに、高温ドレン水を模擬して

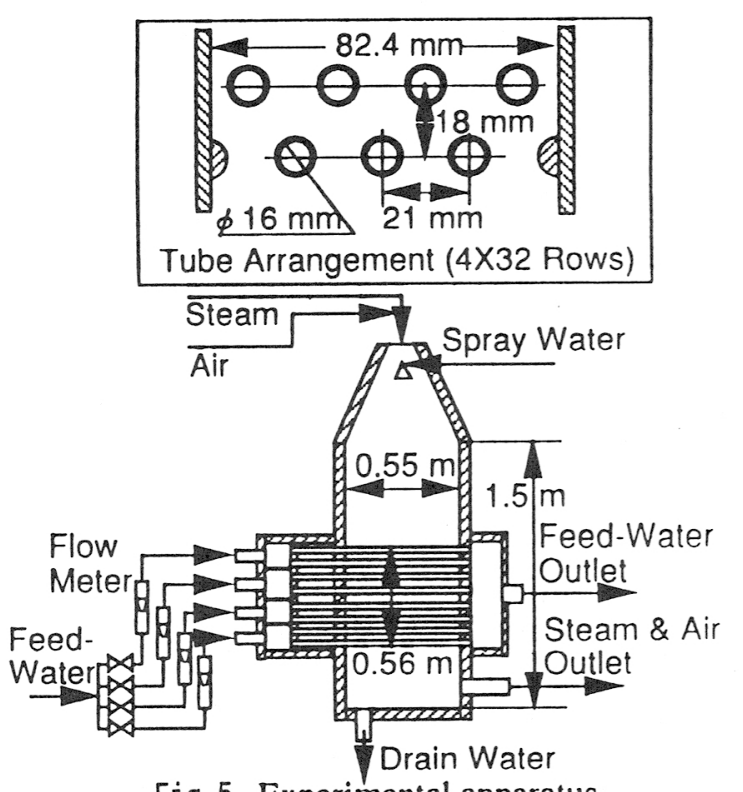

Fig. 5 Experimental apparatus

Table 1 Test conditions

\begin{tabular}{|ll|}
\hline Shell Side & \\
- Pressure & $0.10 \mathrm{MPa}$ \\
- Temperature & $100{ }^{\circ} \mathrm{C}$ \\
- Inlet Flow Rate & $0.03-0.80 \mathrm{~kg} / \mathrm{s}$ \\
- Inlet Quality & $13-100 \%$ \\
- Air Flow Rate & $0-0.003 \mathrm{~kg} / \mathrm{s}$ \\
- Air Molecular Fraction & $0-1.2 \%$ \\
Inside Tubes & \\
- Inlet Temperature & $30-40{ }^{\circ} \mathrm{C}$ \\
- Velocity & $0.74 \mathrm{~m} / \mathrm{s}$ \\
\hline
\end{tabular}

スプレイ水を供給した。不凝縮性気体である空気 は、混入の影響を把握するために実機での条件よ り数桁高い濃度範囲まで測定した。スプレイノズ ルから伝熱管群入口までの距離は750mmであ る。ノズルはキャッッアイ型で穴径 $5 \mathrm{~mm}$ であ り、平均液滴径は $0.1 \mathrm{~mm}$ である。試験部で凝縮し なかった蒸気と空気は、それぞれ試験部下流のポ ストコンデンサで㠜縮し、真空ポンプで排気し た。給水は 4 つの領域で流量が等しくなるように 調整し、各伝熱管に供給した。

伝熱管直径と配置は実機と同一で、4 本× 32 段の伝熱管群を構成したが、1 12 本が伝熱管、 32 本は半割りのダミーロッドである。各伝熱管 の試験部内の長さは $0.55 \mathrm{~m}$ である。各伝熱管の 
出入口温度の測定値から給水のエンタルピー増加 を求め、対数平均温度差と伝熱面積から各伝熱管

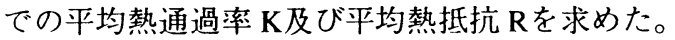
まず、不凝縮性気体を混入しない条件 $\left(\mathrm{R}_{1}=0\right)$ で、式（5）より液膜熱抵抗 $R_{2}=\left(R-R_{3}-R_{4}\right)$ を評 価した。伝熱管材の熱抵抗 $\mathrm{R}_{3}$ は肉厚と熱伝導率 から $\mathrm{R}_{3}=4.153 \times 10^{-6} \mathrm{~m}^{2} \mathrm{~K} / \mathrm{W}$ を使用し、管内熱抵 抗 $\mathrm{R}_{4}$ は強制対流熱伝達の式[12]を用いて計算し た。不凝縮性気体を混入した場合には、同様に、 熱抵抗 $\left(\mathrm{R}_{1}+\mathrm{R}_{2}\right)$ を求め、事前に導出した実験式を 用いて液膜熱抵抗 $R_{2}$ を評価し、凝縮面熱抵抗 $R_{1}$ を分離した。

\section{5. 不凝縮性気体が伝熱に及ぼす影響}

\section{1 実験結果}

凝縮伝熱実験では、試験部入口での蒸気流速は 最大流量約 $0.14 \mathrm{~kg} / \mathrm{s}$ （流速 $5.1 \mathrm{~m} / \mathrm{s}$ ）とした。空気 流量の最大値を $0.003 \mathrm{~kg} / \mathrm{s}$ とし、試験部入口の空 気濃度をモル分率で $0,0.12,0.6,1.2 \%$ に変え

て、凝縮熱伝達率を測定した。

まず、伝熱設計への使用性を考慮し、n 番目の 伝熱管の熱伝達率を表す実験式を導出した。実験 式の導出に当っては、単管外面での凝縮熱伝達率 の理論解[13]より無次元量Bを導入し、ヌッセル 卜理論[14]による伝熱管段数 $\mathrm{n}$ の影響を参照し て、次式を仮定した。

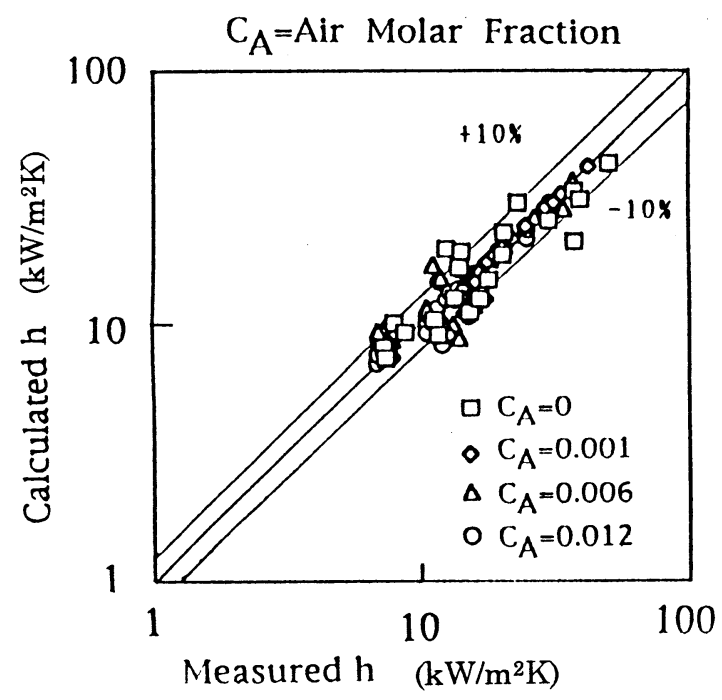

Fig. 6 Accuracy of experimental equations (14)-(16)
$\left(\mathrm{Nu} /\left(\mathrm{Re}_{\mathrm{L}}\right)^{1 / 2}\right)_{\mathrm{n}}=\mathrm{aB}^{\mathrm{b}} \mathrm{n}^{\mathrm{c}}$

$\mathrm{Nu}=\mathrm{hd} / \lambda_{\mathrm{L}}, \quad \operatorname{Re}_{\mathrm{L}}=\mathrm{u}_{\mathrm{s}} \mathrm{d} / \nu_{\mathrm{L}}, \quad \mathrm{B}=\mathrm{Pr}_{\mathrm{L}} / \mathrm{FrH}$,

$\mathrm{Fr}=\mathrm{u}_{\mathrm{s}}{ }^{2} / \mathrm{gd}, \quad \mathrm{H}=\mathrm{Cp}_{\mathrm{L}}\left(\mathrm{T}_{\mathrm{s}}-\mathrm{T}_{\mathrm{Wm}}\right) / \mathrm{L}$

ここで、hは凝縮熱伝達率 $\left(\mathrm{W} / \mathrm{m}^{2} \mathrm{~K}\right) 、 \mathrm{~d}$ は伝熱管 外径 $(\mathrm{m}) 、 \mathrm{u}_{\mathrm{s}}$ は蒸気流速 $(\mathrm{m} / \mathrm{s}) 、 \nu_{\mathrm{L}}$ は水の動粘性係 数 $\left(\mathrm{m}^{2} / \mathrm{s}\right) 、 \mathrm{Re}_{\mathrm{L}}$ は二相レイノルズ数(-)、 $\mathrm{Pr}_{\mathrm{L}}$ は水の プラントル数(-)、gは重力加速度 $\left(\mathrm{m} / \mathrm{s}^{2}\right) 、 \mathrm{Cp}_{\mathrm{L}}$ は水 の定圧比熱 $(\mathrm{J} / \mathrm{kgK}) 、 \mathrm{~T}_{\mathrm{s}}$ は蒸気温度 $(\mathrm{K}) 、 \mathrm{~T}_{\mathrm{Wm}_{\mathrm{m}}}$ は管 外表面の温度 $(\mathrm{K}) 、 \mathrm{~L}$ は潜熱 $(\mathrm{J} / \mathrm{kg})$ である。係数 $\mathrm{a} 、$ 指数b、cは、入口クオリテイx、入口空気濃度 $\mathrm{C}_{\mathrm{A}}$ の関数として、最小二乗フィットにより求めた。

$\mathrm{a}=(0.290+0.85 \mathrm{x})\left(1.0-25 \mathrm{C}_{\mathrm{A}}\right)$,

$\mathrm{b}=0.114+0.10 \mathrm{x}$,

$c=(-0.625+0.30 x)+(14-20) C_{A}$

上式の適用範囲は、

$0.5 \mathrm{~m} / \mathrm{s} \leqq \mathrm{u}_{\mathrm{s}} \leqq 5 \mathrm{~m} / \mathrm{s}, \quad 0.2 \leqq \mathrm{x} \leqq 1.0$,

$0.0 \leqq \mathrm{C}_{\mathrm{A}} \leqq 0.012,0.05 \leqq \mathrm{~B} \leqq 0.5$

である。

Fig. 6 は本研究で導出した実験式(14)-(16)と凝 縮熱伝達率の測定值とを比較したものである。予 測精度は約10\%である。

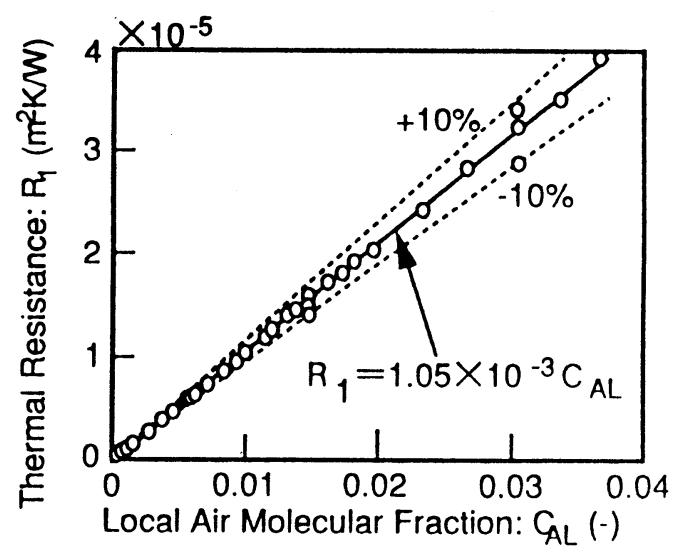

Fig. 7 Thermal resistance due to noncondensable gas 


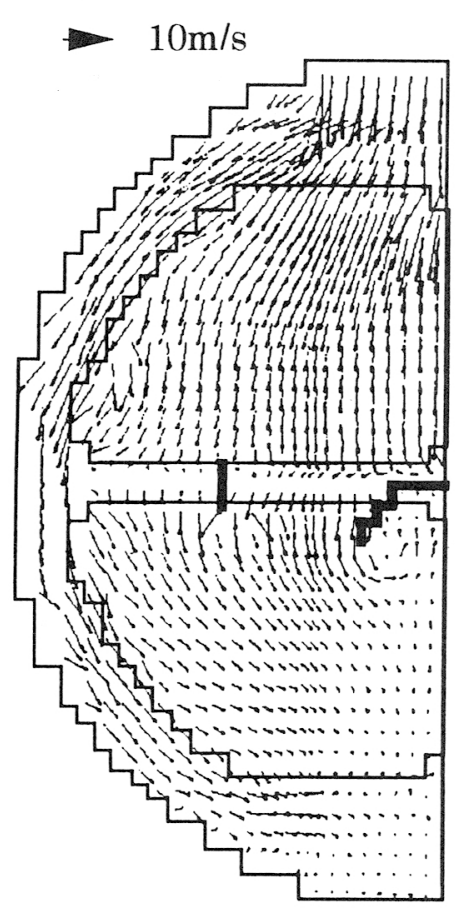

(1)Steam

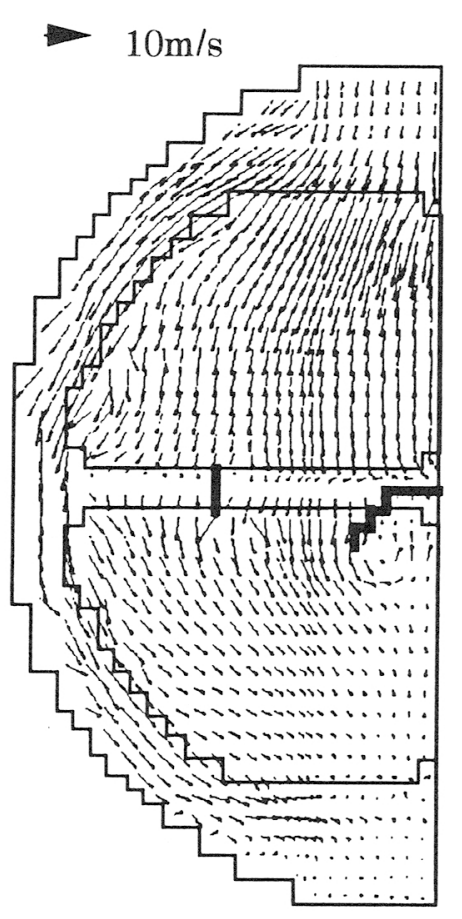

(2)Droplet

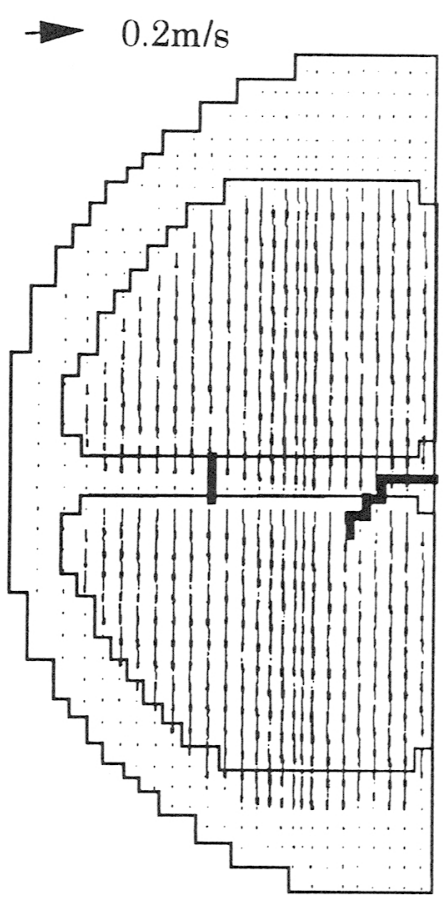

(3)Liquid Film

Fig. 8 Velocity vector distributions of each phase
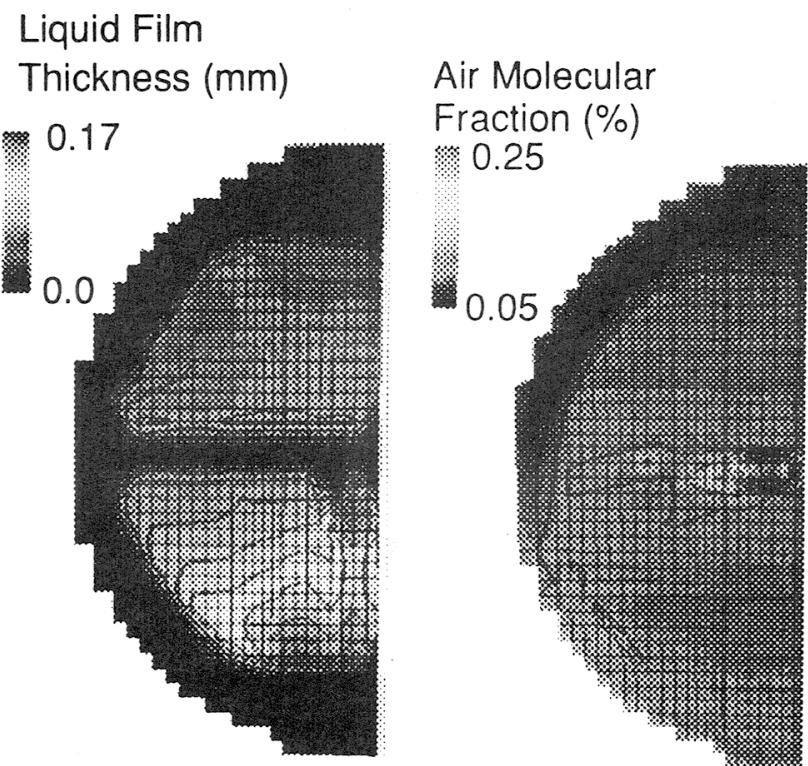

Overall Heat Transfer Coefficient ( $\left.\mathrm{kW} / \mathrm{m}^{2} \mathrm{~K}\right)$

Fig.9 Distributions of liquid film

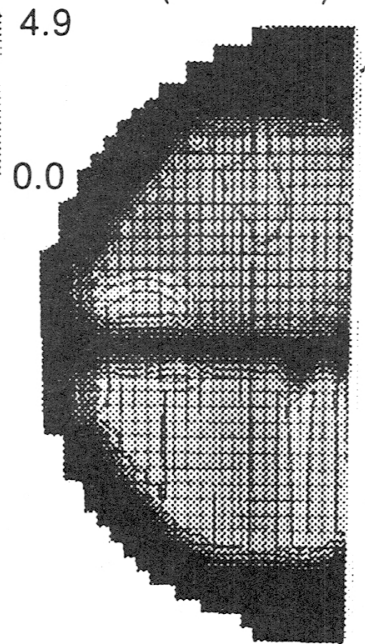

thickness, air molecular fraction

and overall heat transfer coefficient 
本実験式では入口クオリテイ $\mathrm{x} 、$ 空気濃度 $\mathrm{C}_{\mathrm{A}}$ の 影響を含み、式(14)を簡略化しているため、 $\mathrm{x}=$ 1.0、 $\mathrm{C}_{\mathrm{A}}=0$ で従来の式（例えば藤井の式[11]）と 異なるが、熱伝達率は測定誤差10\%の範囲内で一 致する。

数值解析により不凝縮性気体の影響を評価する には、局所での不凝縮性気体濃度と式(5)におけ る凝縮面熱抵抗 $R_{1}$ との関係が必要になる。不凝 縮性気体による凝縮面熱抵抗 $\mathrm{R}_{1}$ の測定結果を

Fig. 7 に示す。局所の不凝縮性気体濃度 $\mathrm{C}_{\mathrm{AL}}$ は、 試験部入口条件と各伝熱管での伝熱量から蒸気凝 縮量を補正して求めた。凝縮面熱抵抗 $\mathrm{R}_{1}$ は局所 での不凝縮性気体濃度に比例する結果が得られ た。

$\mathrm{R}_{1}=\mathrm{eC}_{\mathrm{AL}}, \quad \mathrm{e}=1.05 \times 10^{-3}\left(\mathrm{~m}^{2} \mathrm{~K} / \mathrm{W}\right)$

以下の計算では、凝縮面熱抵抗 $\mathrm{R}_{1}$ には式(18) を使用した。

\section{2 伝熱量解析}

実機給水加熱器の伝熱量解析での条件をTable 2 に示す。流入流量は初期条件であり、計算では 流入した蒸気の全量が凝縮するように調整しなが ら計算する。従って、計算結果として全伝熱量が 得られる。給水は入口温度を入力し、伝熱量計算 の結果から温度上昇を求め、下部伝熱管群、上部 伝熱管群での各平均温度を用いて伝熱計算を実施 した。

粗メッシュによる三次元解析によれば、長手方 向にほほ均等に気相、液相が配分されるので、軸 に垂直な断面内の二次元解析により給水加熱器の 特性を予測できる。そこで、二相流入口での気液 混合流量に蒸気入口での蒸気流量を加えた全流量 の解析領域分を入力して二次元解析とし、給水加 熱器は左右対称形状であることから、対称面から 左側の部分を解析した。

計算結果の一例として、入口の空気モル分率 $0.1 \%$ での各相の流速分布をFig. 8 に、液膜厚 さ、空気モル分率及び熱通過率の分布をFig. 9 に 示す。液滴は蒸気の流れにほほ追従し、蒸気の流 速分布と液滴の流速分布には顕著な相違はない。 蒸気速度は、伝熱管表面での凝縮により、伝熱管 群への流入部から離れた中央部で小さくなってい る。蒸気速度が液膜厚さに及ほす影響は評価して いるが、流速べクトルへの影響は無視しているた
Table 2 Calculation conditions

\begin{tabular}{|ll|}
\hline Shell Side & \\
- Pressure & $1.38 \mathrm{MPa}$ \\
- Temperature & $194{ }^{\circ} \mathrm{C}$ \\
- Inlet Flow Rate & $133 \mathrm{~kg} / \mathrm{s}$ \\
- Inlet Quality & $51 \%$ \\
Inside Tubes & \\
- Inlet Temperature & $155{ }^{\circ} \mathrm{C}$ \\
\hline
\end{tabular}

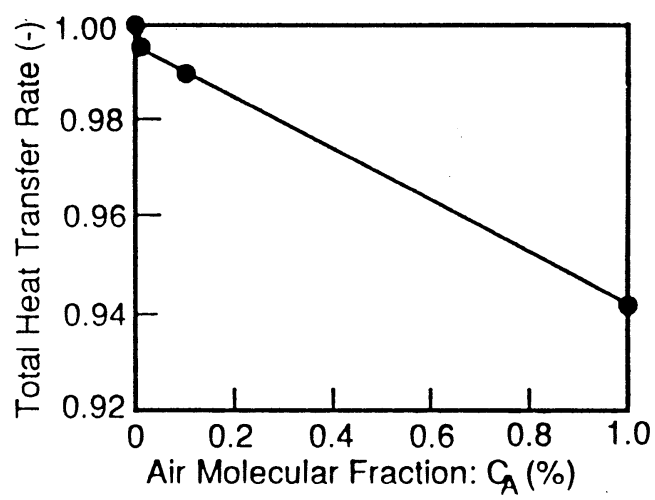

Fig.10 Effect of air molecular fraction on total heat transfer rate

め液膜は鉛直方向に落下している。

液膜厚さは伝熱管群の上部で薄く、下部で厚く なっているが、特に、蒸気速度が小さい伝熱管群 の中央部で厚くなっている。不凝縮性気体である 空気はベント管で排気されるため、ベント管案内 板の内側では濃度が薄く、ベント管案内板の背面 に滞留して濃度が高くなっている。不凝縮性気体 濃度が薄く、熱抵抗への影響が小さいため、熱通 過率は、主として液膜厚さに依存し、液膜厚さが 薄い伝熱管群の上部や外周の蒸気流入部で高く なっている。

入口空気モル分率と全伝熱量との関係をFig. 10 に示す。入口空気モル分率が $1 \%$ と高い場合 には伝熱量に影響するが、実機条件 (約 $30 \mathrm{ppm}$ ) では伝熱量への影響は無視できる程度である。

\section{6. 結 言}

4本x32段の水平伝熱管群を用いた大気圧条件 での実験により、二相流中での管外凝縮熱伝達率 を測定し、不凝縮性気体が凝縮伝熱に及ほす影響 
を評価した。また、二流体モデルと凝縮伝熱モデ ルを用いた給水加熱器内伝熱量解析プログラム

に、不凝縮性気体の輸送方程式と凝縮面熱抵抗の 実験式を追加し、不凝縮性気体が給水加熱器の伝 熱性能に及ほす影響を評価した。

(1)入口クオリテイ13-100\%、空気モル分率0-

$1.2 \%$ 範囲で凝縮熱伝達率を測定し、伝熱管段

数の影響も含めた実験評価式を導出した。導出し

た実験評価式の予測誤差は約 $10 \%$ であった。

(2) 多次元解析で必要となる凝縮面熱抵抗は、局 所の空気モル分率に比例する結果を得た。

(3) 給水加熱器内の二相流・伝熱量解析により、 熱通過率は主として伝熱管外面の液膜厚さに依存 し、蒸気流入部である伝熱管群の上部及び外周部 で熱通過率が高く、伝熱管群の下部や中央部で熱 通過率が低くなることを示した。また、不凝縮性 気体は、ベント管案内板の背面に一部停滞する が、実機条件程度の濃度（約 $30 \mathrm{ppm}$ ) では伝熱量 への影響は無視できることを確認した。

\section{参考文献}

[1] G. Boccardi, Pro. of 2nd Int. Symp. Condensers Condensation, Univ. of Bath, Bath, U.K., pp.28-30 (1990-3).

[2] S. Murata, J. of Nucl. Sci. Technol., Vol.28, No.11, pp.1029-1040 (1991).

[3]高森ほか, 日本機会学会論文集 B 編, Vol.59, No.568, 191-198 (1993).

[4]高森ほか, 日本機会学会論文集 B 編, Vol.61, No.592, 188-193 (1995).

[5]高森ほか, 日本機会学会論文集 B 編, Vol.61, No.583, 428-431 (1993).

[6] A. Minato, J. of Nucl. Sci. Technol., Vol.25, No.12, pp.901-913 (1988).

[7] 日本機械学会編、気液二相流ハンドブック、 コロナ社、pp.39-40 (1989).

[8] P. J. Marto, Heat Transf. Eng., Vol.5, Nos.1-2, pp.31-60 (1984).

[9] 波江、植田、日本機械学会論文集、38巻 308号、pp.821-831 (1972).

[10] 植田、日本機械学会論文集、45巻 389号、 pp.127-135 (1979).

[11] 日本機会学会編、伝熱工学資料、 pp147-150 (1994).

[12] F. P. Incropera, Fundamentals of Heat and Mass Transfer, Wiley, p.496 (1990).
[13] 藤井哲、日本機会学会論文集 B 編, Vol.48, No.436, 2580-2588 (1982).

[14] 甲藤好郎、伝熱概論、養賢堂、 p275 (1987).

\section{Nomenclature}

B $: \mathrm{Pr}_{\mathrm{L}} / \mathrm{FrH} \quad[-]$

$\mathrm{C}_{\mathrm{A}}$ :air molar fraction

$[-]$

$\mathrm{C}_{1}$ :falling liquid film ratio $[-]$

$\mathrm{d}$ : diameter of tube [m]

E :energy transfer between phases due to phase change $\left[\mathrm{W} / \mathrm{m}^{3}\right]$

e :specific internal energy $[\mathrm{J} / \mathrm{kg}]$

$F$ :force per unit volume $\left[\mathrm{N} / \mathrm{m}^{3}\right]$

Fr : Froude number [-]

g :gravity constant $\left[\mathrm{m} / \mathrm{s}^{2}\right]$

$\mathbf{H}$ :ratio of latent heat to apparent heat $[-]$

$\mathrm{K}$ :momentum transfer between phases due to phase change $\quad\left[\mathrm{kg} / \mathrm{m}^{3} \mathrm{~s}^{2}\right]$

$\mathrm{Nu}:$ Nusselt number $\quad[-]$

$n$ :row number of tubes [-]

$\mathrm{P}$ :pressure [Pa]

$\mathrm{Pr}_{\mathrm{L}}$ :Prandtl number $\quad[-]$

$\mathrm{q}$ :heat input per unit volume $\left[\mathrm{W} / \mathrm{m}^{3}\right]$

$\operatorname{Re}_{\mathrm{L}}: \mathrm{u}_{\mathrm{s}} \mathrm{d} / \nu_{\mathrm{L}} \quad[-]$

$t$ :time [s]

$\mathrm{U}$ :velocity $[\mathrm{m} / \mathrm{s}]$

$\mathrm{u}_{\mathrm{s}}$ :steam velocity $[\mathrm{m} / \mathrm{s}]$

$\mathrm{x}$ :inlet quality $[-]$

(Greek letter)

$\alpha$ :volumetric fraction [-]

$\Gamma$ :mass transfer between phases due to phase change $\left[\mathrm{kg} / \mathrm{m}^{3} \mathrm{~s}\right]$

$\gamma_{\mathrm{s}}$ :surface permeability $[-]$

$\gamma_{\mathrm{v}}$ :volume porosity $[-]$

$\nu_{\mathrm{L}}$ : viscosity $\left[\mathrm{m}^{2} / \mathrm{s}\right]$

$\rho$ :density $\left[\mathrm{kg} / \mathrm{m}^{3}\right]$

$\tau$ :shear stress per unit volume $\left[\mathrm{N} / \mathrm{m}^{3}\right]$

(Subscript)

I :interface between gas and liquid

k :phase

L :liquid phase

$s$ :structure

w :wall 